\title{
NETTLE (Urtica dioica L.) SEEDS AS A SOURCE OF FREE AND BOUND PHENOLICS: THE ANTIOXIDANT, ANTIMICROBIAL ACTIVITY AND THE COMPOSITION
}

Jelena S. Mitrović ${ }^{\star}$, Nada Č. Nikolić, Ivana T. Karabegović, Bojana R. Danilović, Miodrag M. Lazić, Ljubiša B. Nikolić

University of Niš, Faculty of Technology, Leskovac, Serbia

In this study, the composition and the antioxidant and antimicrobial activity of free and bound phenolics from Urtica dioica L. seeds were studied. The composition of phenolics was determined by isocratic and gradient HPLC methods, and the antioxidant activity by determining DPPH scavenging capacity, reducing the power and FRAP value. The antimicrobial activity was tested by using the discdiffusion method. The content of free phenolics was higher $(6000.71 \mu \mathrm{g}$ gallic acid equivalent per $\mathrm{g}$ dry seeds mass) than the content of bound phenolics $\left(2801.16 \mu \mathrm{g} \mathrm{g}^{-1}\right)$. The extract of free phenolics had a higher FRAP value than the bound, while the bound phenolics had a better DPPH scavenging capacity and the reducing power. Eighteen phenolics have been detected in the free phenolic extract, among which kaempferol 3-O-rutinoside-7-O- rhamnoside was the most abundant (428.55 $\mathrm{\mu g} \mathrm{g}^{-1}$ ), while ten phenolics have been detected in the bound phenolic extract, among which monocaffeoyl-meso-tartaric acid $\left(406.83 \mu g^{-1}\right)$ was the most abundant. Both of the extracts have shown a good inhibitory effect on Bacillus cereus ATCC 11778 and Klebsiella pneumoniae ATTC 700603. The study showed that nettle seeds are a good source of natural antioxidants and antimicrobials for potential use in the food and pharmaceutical industry.
(ORIGINAL SCIENTIFIC PAPER) UDC 582.635.5:547.56:543.2

Keywords: phenolics, nettle seeds, antioxidant activity, antimicrobial activity

\section{Introduction}

Urtica dioica L., also known as stinging nettle, is a perennial flowering herb that belongs to the Urticaceae family. It is known as a cosmopolitan plant, widespread throughout moderate and tropical areas [1]. This plant is a good source of secondary metabolites such as tannins, terpenoids, alkaloids, and flavonoids, but it is also rich in minerals, especially iron, vitamin $C$ and pro-vitamin $A[2,3]$. Since ancient times, nettle has been used in traditional medicine due to its therapeutic potential and a wide spectrum of activities such as antioxidant, antimicrobial, antiulcer, analgesic, diuretic, antidiabetic, anti-inflammatory and antirheumatic [4].

The antioxidant activity is mainly expressed as the ability to scavenge free radicals [5] which are continuously formed in biological systems as a result of normal metabolism or a disease. Free radicals are unstable molecules or highly reactive ions that start chemical reactions with almost all classes of biomolecules, and tend to damage a number of cellular systems changing their functions. In the literature, there are many studies regarding the evaluation of the antioxidant activity of various parts of plant extracts, mainly leaves [6]. The investigations of Singh et al.[7] showed that the antioxidant activity of seeds is generally increased during the germination, and this was confirmed by Lin and Lai [8] for mature and germinated seeds of selected legume varieties including soybeans, azuki and mung beans. The increase in the antioxidant activity, measured as the inhibition of peroxidation was observed by Hudec et al. [9] after the root, stem, and leaf of the nettle plant treatment by $\mathrm{O}$ phosphoethanolamine and carboxymethyl chitin glucan.

Phenolics are believed to be the effective plant antioxidants for maintaining the cellular redox status, and they are one of the most numerous and structurally diverse plant phytochemicals which are synthesized during the normal development of a plant or as a response to stress (infection, temperature, UV-irradiation) [10]. They can be classified in diversified categories such as flavonoids, phenolic acids, phenolic polymers (hydrolyzable and condensed tannins), stilbenes and lignans [11]. In radical-scavenging reactions, the phenolics take part as donors of electrons and form stable radicals [12] protecting biomolecules (such as proteins, nucleic acids, polyunsaturated lipids, and sugars) from oxidation. Many earlier studies have been dealing with the antioxidants of free phenolics. However, in order to consider the total antioxidant activity, it is important to study the bound phenolics too.

In our available literature, there are many studies concerning the content, antioxidative and antimicrobial activities of phenolics from various parts of Urtica dioica L.,

\footnotetext{
*Author address: Jelena Mitrović, Faculty of Technology, University of Niš, Bulevar oslobodjenja 124, 16000 Leskovac, Serbia

E-mail: mitrovic_jelena91@hotmail.com

The manuscript received: December, 23, 2019.

Paper accepted: January, 22, 2020.
} 
especially leaves, but the appropriate data about these compounds, especially bound phenolics from seeds are missing. Therefore, the aim of the present research is to estimate the content and composition of both free and bound phenolics, their antioxidative and antimicrobial activities, as well as to assess nettle seeds as a source of antioxidants and antimicrobials for the potential usage in food and pharmaceutical industry.

\section{Materials and methods}

\section{Plant material}

A sample of Urtica dioica L. seeds was purchased from "Jeligor", Svrljig in Serbia. The nettle seeds were ground in an electric grinder (Bosh, MKM 600, Germany) and sieved through a $0.40 \mathrm{~mm}$ riddle.

\section{Extraction of free phenolics}

A free phenolics extract was prepared by $30 \mathrm{~g}$ of the sample and $150 \mathrm{~mL}$ of $70 \%$ methanol. The extraction was carried out at room temperature for $24 \mathrm{~h}$, with occasional stirring.

The extract was separated by filtration and the seeds remnant left from the filtration was used as a material for a re-extraction process. Methanol $(20 \mathrm{~mL})$ was added to the remnant and the extraction was carried out at room temperature for 30 minutes. The re-extract was separated by filtration, the filtrates were combined and a final volume of $150 \mathrm{~mL}$ was made by methanol in order to obtain the extract of free phenolics for further analysis. To obtain different concentrations of the extract, the appropriate dilutions ranging from 1:1 to $1: 10(\mathrm{v} / \mathrm{v})$ were made. In order to carry out HPLC analysis of the free phenolics composition, the extract was filtered through a $0.45 \mu \mathrm{m}$ Millipore filter (Millipore Corporation, Billerica, MA, USA). The extraction procedure was performed in triplicate, and the seeds from which free phenolics had been extracted were preserved and used for the extraction of bound phenolics.

\section{Extraction of bound phenolics}

The bound phenolics were liberated by alkaline hydrolysis, as described by Verma et al. [13]: $30 \mathrm{~g}$ of the seeds from which free phenolics had been removed, $900 \mathrm{~mL}$ of distilled water and $150 \mathrm{~mL}$ of $6 \mathrm{M} \mathrm{NaOH}$ were mixed and left at room temperature for $24 \mathrm{~h}$. The $\mathrm{pH}$ of mixture was adjusted to 2 with $5 \mathrm{M} \mathrm{HCl}$, and $800 \mathrm{~mL}$ of diethyl ether and the ethyl acetate mixture in the ratio of $1: 1(\mathrm{v} / \mathrm{v})$ was added. The mixture was shaken for every 30 minutes during $3 \mathrm{~h}$ and left overnight. The upper layer was then removed and evaporated by rotary evaporation (IKA®-WERKE, RV06ML, Germany) until it was dry. The dry residue was dissolved in $200 \mathrm{~mL}$ of $70 \%$ methanol. To obtain different concentrations of the extract, dilutions in the same range as in the case of the free phenolics extract were made. Before HPLC analysis, the extract was filtered through a $0.45 \mu \mathrm{m}$ filter as in the case of free phenolics.
Determination of the total phenolics content

The total phenolic content of the extracts was assayed as described by Singleton and Rossi [14] by using the Folin-Ciocalteu colorimetric method with final reaction measurements at $765 \mathrm{~nm}$. The extract of free or bound phenolics $(0.5 \mathrm{~mL})$ was mixed with $0.5 \mathrm{~mL}$ of Folin-Ciocalteu reagent and $4.5 \mathrm{~mL}$ of deionized water, and $7.5 \%$ aqueous $\mathrm{Na}_{2} \mathrm{CO}_{3}(5 \mathrm{~mL}, \mathrm{w} / \mathrm{v})$ was added after $5 \mathrm{~min}$. After 90 minutes of incubation, the absorbance was measured by using UV 2100 Spectrophotometer (Cole Parmer Instrument Company, Vernon Hills, Illinois, USA). The blank was prepared by using the same procedure, whereby the extract was replaced with an equal volume of deionized water. The phenolics content was calculated by using the equation $\left(C=175.44 \times A_{b}-5.30, R^{2}=0.9959, \mu g \mathrm{~mL}^{-1}\right)$ of the calibration curve obtained with gallic acid in the concentration range 0 to $300 \mu \mathrm{g} \mathrm{mL}^{-1}$. The phenolics content was calculated to $\mu \mathrm{g}$ of gallic acid equivalent (GAE) per $g$ of the dry plant material.

\section{DPPH radical scavenging capacity (DPPH SC)}

The SC of the extracts of free and bound phenolics was determined by the method described by Mensor et al. [15]. The absorbance at $517 \mathrm{~nm}$ was measured and converted into the percentage of radical SC (\%):

DPPH SC (\%) $=100-\left[\left(A_{\text {sample }}-A_{\text {blank }}\right) \frac{100}{A_{\text {control }}}\right]$.

where Asample is the absorbance at $517 \mathrm{~nm}$ of the extract in methanol $(2.5 \mathrm{~mL})$ treated by the DPPH radical solution, Ablank is the absorbance at $517 \mathrm{~nm}$ of the extract in methanol ( $1 \mathrm{~mL}$ of methanol added to $2.5 \mathrm{~mL}$ of the extract), and Acontrol is the absorbance at $517 \mathrm{~nm}$ of methanol of the DPPH radical $(1 \mathrm{~mL}$ of a $0.3 \mathrm{mM}$ added to $2.5 \mathrm{~mL}$ of methanol). The $\mathrm{IC}_{50}$ value was determined by using Microsoft Excel ed50plus v1.0 software (INER/México) and expressed as $\mathrm{mg}$ of the dried residue per $\mathrm{mL}$. Butylated hydroxyanisole (BHA) was used as a standard.

\section{Reducing power}

The reducing power of the extracts was determined by measuring the absorbance at $700 \mathrm{~nm}$ as described by Oyaizu [16]. Various concentrations of the dry residue of the free and bound phenolics extract $\left(0.5\right.$ to $\left.8.5 \mathrm{mg} \mathrm{mL}^{-1}\right)$ were mixed with $2.5 \mathrm{~mL}$ of the $0.2 \mathrm{M}$ phosphate buffer ( $\mathrm{pH} 6.6)$ and $2.5 \mathrm{~mL}$ of potassium ferricyanide (1\%). The mixture was incubated at $50{ }^{\circ} \mathrm{C}$ for $20 \mathrm{~min}$. Then, $2.5 \mathrm{~mL}$ of trichloroacetic acid $(10 \%)$ was added and the mixture was centrifuged at $3000 \mathrm{rpm}$ for $10 \mathrm{~min}$. Supernatant $(2.5 \mathrm{~mL})$ was mixed with redistilled water $(2.5 \mathrm{~mL})$ and $0.5 \mathrm{~mL}$ of the ferric chloride solution $(0.1 \%)$, while the absorbance was measured at $700 \mathrm{~nm}$. Using Microsoft Excel ed50plus v1.0 software, the $\mathrm{IC}_{50}$ value was determined (INER/México) and expressed as mg of the dried residue per $\mathrm{mL}$, while $\mathrm{BHA}$ was used as a standard. 
Ferric reducing antioxidant power (FRAP)

The FRAP of methanol extracts was measured according to the method of Benzie and Strain [17] with some modifications: the extracts $(0.2 \mathrm{~mL})$ were mixed with $6 \mathrm{~mL}$ of the FRAP reagent in test tubes and subjected to Vortex-induced vibrations. After 30 min of incubation at $37^{\circ} \mathrm{C}$ in the water bath, the absorbance was measured at $593 \mathrm{~nm}$. A blank sample was prepared with methanol $(0.2 \mathrm{~mL})$ and the FRAP reagent $(6 \mathrm{~mL})$.

To determine a FRAP value, the amount of the standard solution $(0.2 \mathrm{~mL})$ of $\mathrm{FeSO}_{4} \times 7 \mathrm{H}_{2} \mathrm{O}$ in the concentration range $0-350 \mu \mathrm{g} \mathrm{mL}^{-1}$ was mixed with $6 \mathrm{~mL}$ FRAP reagent. The calibration curve was designed based on absorbance values and the investigated concentrations of $\mathrm{FeSO}_{4} \times 7 \mathrm{H}_{2} \mathrm{O}$ solutions ( $\mathrm{C}_{\mathrm{FeSO} \times \mathrm{TH} 2 \mathrm{O}}=1.6 \mathrm{Ab}+14.6 \times 10^{-3}, \mathrm{mmol} \mathrm{Fe}^{2+} \mathrm{L}^{-1}$ ). The FRAP value is expressed as $\mu \mathrm{mol} \mathrm{Fe}^{2+} \mathrm{g}^{-1}$ of the dry plant material. Analogous tests were carried out with $\mathrm{BHA}$ as a standard.

\section{HPLC analysis}

The isocratic HPLC method [18] was used to determine the phenolic acids composition. The content of phenolic acid was calculated based on the calibration curve obtained for each phenolic acid separately [19]. In order to test the extracts to hydroxycinnamic acid, caffeoylshikimic and monocaffeoyl-meso-tartaric acid and kaempferol and quercetin derivates, the HPLC method by the gradient elution program [20] was applied. Due to poor reproducibility, the relative retention indices were calculated as the ratio between the retention time of the compound and naringenin as the internal standard. The peak identity was checked by comparison of their relative retention indices with the previous ones and with reference compounds (hydroxycinnamic acid, 5-O-caffeoylshikimic acid, and quercetin 3-O-rhamnoside purchased from Sigma Chemical, St. Louis, Missouri, USA). The content of these compounds was calculated based on the HPLC peak area and the corresponding calibration curve, and the mass of other compounds was quantified based on the calibration curve of the most similar compound by retention time.

\section{Antimicrobial activity determination}

The antimicrobial activity was analysed using nine bacterial strains: Proteus vulgaris ATCC 8427, BacilIus cereus ATCC 11778, Bacillus luteus, Bacillus subtilis, Staphylococcus aureus ATCC 25923, Escherichia coli ATCC 25922 and Pseudomonas aeruginosa ATTC 27853, Listeria monocytogenes ATCC 15313, Klebsiella pneumoniae ATTC 700603 and one fungal strain Candida albicans ATCC 10259. Microorganisms were cultivated on Nutrient agar (Torlak, Belgrade, Serbia) for bacterial, and Sabouraud maltose agar (Torlak, Belgrade, Serbia) for the fungi growth. The mediums were sterilized for 15 minutes in the autoclave at $121^{\circ} \mathrm{C}$ and under the pressure of $101 \mathrm{kPa}$, and the antimicrobial activity was determined by using the agar discdiffusion method [21]. In order to achieve the cell number of $1 \times 10^{8} \mathrm{CFU}$
$\mathrm{mL}^{-1}$, the inoculums of the strains were prepared by suspending the culture in the sterile $0.8 \% \mathrm{NaCl}$ solution and adjusting the turbidity value to $0.5 \mathrm{McF}$ arland standard. Afterward, the suspension was swabbed on the surface of solidified agar plates. Paper disks (diameter $6 \mathrm{~mm}$ ) were impregnated with $30 \mu \mathrm{L}$ of the extracts and placed on the inoculated agar surface. The incubation was performed at $37^{\circ} \mathrm{C}$ for $24 \mathrm{~h}$ for bacterial, and at $28^{\circ} \mathrm{C}$ for 48 $\mathrm{h}$ for fungi strains. The antimicrobial activity was determined by measuring the diameter of the inhibition zone.

\section{Statistical analysis}

The results were presented as the mean of three determinations \pm standard deviation. In order to compare the differences in mean values of the content of free and bound phenolics in the obtained extracts, a statistical analysis by t-test at the $5 \%$ level was done.

\section{Results and discussion}

\section{Phenolics content}

The content of free and bound phenolics in the nettle seeds is shown in Table 1.

Table 1. The content of phenolics, I $\mathrm{C}_{50}$ value for the DPPH and the reducing power and FRAP value for the extracts of free and bound phenolics from nettle seeds

\begin{tabular}{|c|c|c|}
\hline & $\begin{array}{l}\text { Extract of free } \\
\text { phenolics }\end{array}$ & $\begin{array}{l}\text { Extract of bound } \\
\text { phenolics }\end{array}$ \\
\hline Extract dry matter & $13.46 \pm 0.98^{\mathrm{a}}$ & $8.45 \pm 1.01^{b}$ \\
\hline Phenolics content" & $6000.71 \pm 28.81^{\mathrm{a}}$ & $2801.16 \pm 49.31^{b}$ \\
\hline Total"* & \multicolumn{2}{|c|}{$8801.87 \pm 57.11$} \\
\hline $\mathrm{IC}_{50}, \mathrm{DPPH} \mathrm{SC}^{* * * *}$ & $0.73 \pm 0.14^{\mathrm{a}}$ & $0.38 \pm 0.09^{b}$ \\
\hline $1 / / \mathrm{C}_{50}$ & 1.37 & 2.63 \\
\hline $\begin{array}{l}\text { Phenolics content in dry matter of } \mathrm{IC}_{50} \text { value } \\
\text { of DPPH SC } \mathrm{SC}^{* *}\end{array}$ & $65.09 \pm 12.48^{\mathrm{a}}$ & $18.89 \pm 8.95^{b}$ \\
\hline $\mathrm{IC}_{50}$, Reducing power ${ }^{* * *}$ & $5.68 \pm 0.55^{a}$ & $1.43 \pm 0.2^{b}$ \\
\hline $1 / / C_{50}$, Reducing power & 0.18 & 0.70 \\
\hline $\begin{array}{l}\text { Phenolics content in dry matter of } \mathrm{IC}_{50} \text { value } \\
\text { of reducing power }\end{array}$ & $506.44 \pm 49.04^{a}$ & $71.10 \pm 19.89^{b}$ \\
\hline FRAP value ${ }^{* * * *}$ & $37.85 \pm 1.75^{\mathrm{a}}$ & $27.16 \pm 2.32^{b}$ \\
\hline BHA equivalent for FRAP value ${ }^{* * *}$ & $157.35 \pm 35.96^{a}$ & $563.14 \pm 47.79^{b}$ \\
\hline $\begin{array}{l}\text { Within rows, the values assigned to different } \\
{ }^{*} \mathrm{mg} \text { dried residue per } \mathrm{mL} \\
{ }^{* \star} \mu \mathrm{g} \text { gallic acid equivalent per } \mathrm{g} \text { of the dry } \mathrm{p} \\
{ }^{\star \star \star} \mu \mathrm{g} \text { of dry residue per } \mathrm{mL} \\
{ }^{\star \star \star \star} \mu \mathrm{mol} \mathrm{Fe}^{2+} \text { per } \mathrm{g} \text { of the dry plant material }\end{array}$ & $\begin{array}{l}(a, b) \text { are signifi } \\
\text { terial }\end{array}$ & different at $P<0.0$ \\
\hline
\end{tabular}

The results show that the content of phenolics in the extract of free phenolics $\left(6000.71 \mathrm{\mu g} \mathrm{g} \mathrm{g}^{-1}\right)$ was significantly $(p<0.05)$ higher than in the extract of bound phenolics $\left(2801.16 \mu^{\prime g ~ g}{ }^{-1}\right)$.

Most of the previously published results consider the content of phenolics extracted from other parts of nettle plants, especially leaves, and point out the dependence of the phenolics content on the used solvent, the extraction technique and the geographical origin of the plant [22-27]. Our results are similar to the results of the total phenolics content in roots, stalks, and leaves of nettle of 7.82, 9.91, $7.62 \mathrm{mg}$ GAE per g dry mass, respectively, reported by Hudec et al. [9]. In some papers, the content of the phenolics is expressed in $\mu \mathrm{g}$ per dry residue of the extract, so it is not possible to properly compare the 
results with the results obtained in this research. Thus, the phenolics content of 208.37 mg GAE per $g$ dry matter extract was found in the nettle leaves extracts obtained by using $80 \%$ ethanol $(\mathrm{v} / \mathrm{v})$ and ultrasonic extraction at $30 \mathrm{~Hz}$ [27]. The extracts obtained by Soxhlet extraction showed that the phenolics content was in the range 1.27-24.22 mg GAE per $g$ dry mass of the solvent fraction, depending on the solvent (hexane, benzene, chloroform, diethyl ether, ethyl acetate, acetone, ethanol, methanol, and water) and solvent ratios [25].

\section{Antioxidant activity}

In Table 1, IC 50 values of DPPH SC and the reducing power, as well as FRAP values are shown. Since the lower $\mathrm{IC}_{50}$ values show higher DPPH RSC and the reducing power, the reciprocal $\mathrm{IC}_{50}$ values are calculated to obtain the proper dependence.

The extract of bound phenolics showed $\mathrm{IC}_{50}$ of 0.38 $\mathrm{mg} \mathrm{mL}^{-1}$ and the extract of free phenolics, $0.73 \mathrm{mg} \mathrm{mL}^{-1}$ for DPPH SC, indicating that the bound phenolics have better DPPH SC, and the difference is statistically significant $(p<0.05)$. In literature, there are data of $I_{50}$ values for free phenolics extracted by $50 \%$ aqueous-methanolic extracts from nettle leaves in the range of $0.105-132 \mathrm{mg}$ $\mathrm{mL}^{-1}$ [28] and for free phenolics extracted by using the $5 \%$ aqueous-ethanolic extract $\mathrm{IC}_{50}$ was $1.2 \mathrm{mg} \mathrm{mL}^{-1}$ [29]. Similar results were achieved for the extract obtained by using $54 \%$ aqueous-methanol by maceration and ultrasound-assisted extraction [30] when $\mathrm{IC}_{50}$ was 0.293$0.337 \mathrm{mg} \mathrm{mL}^{-1}$ and $0.226-0.240 \mathrm{mg} \mathrm{mL}^{-1}$, respectively. A higher $\mathrm{IC}_{50}$ value of $88.33 \mu \mathrm{g} \mathrm{mL} \mathrm{m}^{-1}$ for DPPH SC was reported by Khare et al. [31] for phenolics of the aerial part of the nettle extracted by two steps of the Soxhlet extraction first by $98 \%$ petroleum and then by $50 \%$ hydroalcohol, as well as by Zeković et al. [26] when IC 50 values of $29.77,21.47$ and $16.93 \mu \mathrm{g} \mathrm{mL}^{-1}$ were obtained for the extracts from nettle leaves by using ultrasound-assisted, microwave-assisted and subcritical water extraction, respectively. The higher antioxidant activity probably exists due to a different composition of the extracted phenolics. They are extracted by using different solvents, techniques and plant parts.

The presented results in Table 1 show that besides DPPH SC, the extract of bound phenolics has a statistically higher reducing power $\left(\mathrm{IC}_{50}\right.$ was $\left.1.43 \mathrm{mg} \mathrm{mL}^{-1}\right)$ compared to the extract of free phenolics $\left(5.68 \mathrm{mg} \mathrm{mL}^{-1}\right.$, respectively) $(p<0.05)$. In available literature, there are data concerning the reducing power of methanol extracts obtained by Soxhlet extraction of phenolics from nettle leaves [32], when $\mathrm{IC}_{50}$ was $125 \mathrm{mg} \mathrm{mL}^{-1}$, and the water extract from aerial parts of the nettle achieved by Gülçin et al. [5] when the $\mathrm{IC}_{50}$ value was $110 \mathrm{mg} \mathrm{mL}^{-1}$. Compared to our results, it is evident that phenolics from the seeds have a stronger reducing power than phenolics from the aerial parts of nettle. On the other hand, the extracts of nettle leaves obtained by novel techniques of the extraction such as ultrasound, microwave, and a subcritical water extraction showed a stronger reducing power: $\mathrm{IC}_{50}$ values were 43.93, 35.60 and $30.07 \mu \mathrm{g} \mathrm{mL}^{-1}$, respectively [26].

The results of FRAP values show that the extract of free phenolics had a higher value $\left(37.85 \mu \mathrm{mol} \mathrm{Fe}{ }^{2+}\right.$ per $\mathrm{g}$ of dry plant material, i.e. $\left.7.57 \mathrm{mM} \mathrm{Fe}^{2+} / \mathrm{L}\right)$ than the extract of bound phenolics $\left(27.16 \mu \mathrm{mol} \mathrm{g}^{-1}\right.$, i.e. $3.87 \mathrm{mM}$ $\left.\mathrm{Fe}^{2+} / \mathrm{L}\right)$. The BHA equivalent for free and bound phenolics was 157.35 and $563.14 \mu \mathrm{g} \mathrm{mL}^{-1}$, respectively and the difference is statistically significant $(p<0.05)$. The results are in accordance with Cvitanović et al. [33] investigations who reported the FRAP values in the range of 2.38-13.47 mM $\mathrm{Fe}^{2+} / \mathrm{L}$ for the extracts from nettle leaves obtained by infusion, maceration, and decoction.

Differences in the antioxidant activity between the extracts of free and bound phenolics could be explained by the content and the composition of phenolics (different in the chemical structure and the content of individual compounds) which show a different antioxidant activity depending on the applied method for investigation [34].

In order to compare the DPPH SC and reducing the power of the investigated extracts to BHA, the content of phenolics contained in the dry residues of $\mathrm{IC}_{50}$ values were calculated and also presented in Table 1. For the DPPH SC test, standard BHA had the $\mathrm{IC}_{50}$ value of $2.27 \mathrm{\mu g} \mathrm{mL}^{-1}$ and for the reducing power test it was $16.34 \mu \mathrm{g} \mathrm{mL}^{-1}$. These results indicate that the extract of free phenolics has 28.7 times weaker DPPH SC and 30.4 times weaker reducing power. The extract of bound phenolics has 8.3 times weaker DPPH SC and the 2.3 times weaker reducing power than BHA.

Comparing the extract of free phenolics to the extract of a bond, the bound phenolics had better DPPH SC and the reducing power. The reason for that may be a higher content of caffeic acid in the extract of bound than in the extract of free phenolics, as well as tannic acid, monocaffeoyl-meso-tartaric acid, NID 1 and NID2 that are present only in the extract of bound phenolics (Table 2). The investigation of Chen and $\mathrm{Ho}$ [35] supported this fact by showing that the caffeic acid had a better DPPH $\mathrm{SC}$ than chlorogenic and ferulic acids. The investigation of Masek et al. [36] also shows that in comparison to $p$-coumaric acid, the caffeic acid exhibited better antioxidant properties investigated by DPPH, FRAP and CUPRAC methods.

\section{Composition of phenolics}

The results of the composition of free and bound phenolic acids, rutin and myricetin in the extracts, determined by HPLC isocratic elution, are presented in Table 2. In the extract of free phenolics, nine phenolics had been detected, while in the extract of bound phenolics, seven. Among these phenolics, the chlorogenic acid was the most abundant in the extract of free phenolics (323.72 $\left.\mu \mathrm{g} \mathrm{g}^{-1}\right)$, and the caffeic acid in the extract of bound phenolics $\left(165.49 \mu \mathrm{g} \mathrm{g}^{-1}\right)$. In the extract of free phenolics, the content of gallic, chlorogenic and transferulic acid and rutin was 17.5, 15.3, 4.9 and 49.4 times higher, respectively, compared to the extract of bound phenolics. On the other hand, in the extract of bound 
phenolics, the content of caffeic and coumaric acid was 7.3 and 6.9 times higher, respectively, than in the extract of free phenolics. The obtained results by Pinelli et al. [37] showed that the leaves of cultivated and wild nettle contain large amounts of chlorogenic and 2-O-caffeoylmalic acid, which represented over $70 \%$ of total phenolics, respectively. By using LC/MS and HPLC analysis, Vajić et al. [30] detected the chlorogenic acid, rutin, and 2-O-caffeoyl malic acid as the most abundant phenolics in the extracts obtained by maceration and ultrasoundassisted extraction of phenolics from stinging nettle leaves. Furthermore, the investigations of Otles and Yalcin [22] showed that different plant parts of nettle (root, stalk, and leaves) collected from different regions of Turkey have a different composition and content of phenolics, where the content of syringic acid was the most abundant in fresh leaves of one sample of nettle from Aegean region. Based on the presented data, it might be concluded that the nettle has different quantitative and qualitative profiles of phenolics depending on the part of a plant, growing region, extraction techniques, solvents used for the extraction etc. Therefore, it is necessary to examine each part of the plant separately.

Table 2. The content of phenolic compounds in the extracts of free and bound phenolics from nettle seeds identified by an isocratic HPLC method

\begin{tabular}{lccc}
\hline Content of compound $\left(\mu \mathrm{g} \mathrm{g}^{-1}\right)^{\circ}$ & $\begin{array}{c}\text { Extract of free } \\
\text { phenolics }\end{array}$ & $\begin{array}{c}\text { Extract of bound } \\
\text { phenolics }\end{array}$ & Total free and bound \\
\hline Gallic acid & $149.27 \pm 13.43^{\mathrm{a}}$ & $8.51 \pm 1.18^{\mathrm{b}}$ & $157.78 \pm 13.48$ \\
Chlorogenic acid & $323.72 \pm 27.50^{\mathrm{a}}$ & $21.19 \pm 5.69^{\mathrm{b}}$ & $344.91 \pm 28.08$ \\
Caffeic acid & $22.51 \pm 2.03^{\mathrm{a}}$ & $165.49 \pm 12.4^{\mathrm{b}}$ & $188.00 \pm 12.57$ \\
Tannic acid & - & $52.47 \pm 3.67$ & $52.47 \pm 3.67$ \\
Syringic acid & $11.46 \pm 0.92$ & - & $11.46 \pm 0.92$ \\
Ellagic acid & $94.75 \pm 8.05$ & - & $94.75 \pm 8.05$ \\
Coumaric acid & $1.66 \pm 0.15^{\mathrm{a}}$ & $11.47 \pm 0.80^{\mathrm{b}}$ & $13.13 \pm 0.15$ \\
Trans-ferulic acid & $49.74 \pm 3.48^{\mathrm{a}}$ & $10.22 \pm 0.92^{\mathrm{b}}$ & $59.96 \pm 3.59$ \\
Rutin & $216.04 \pm 17.28^{\mathrm{a}}$ & $4.37 \pm 0.39^{\mathrm{b}}$ & $220.41 \pm 17.28$ \\
Myricetin & $34.47 \pm 2.75$ & - & $34.47 \pm 2.75$ \\
Total & $\mathbf{9 0 3 . 6 2 \pm 3 6 . 3 9}$ & $\mathbf{2 7 3 . 7 2 \pm 1 4 . 2 4}$ & $\mathbf{1 1 7 7 . 3 4} \pm 39.07$ \\
\hline Within rows, the values assigned to different letters (a,b) are significantly different at $\mathrm{P}<0.05$
\end{tabular}

Table 3. The content of phenolic compounds in the extracts of free and bound phenolics from nettle seeds identified by a gradient HPLC method

\begin{tabular}{|c|c|c|c|}
\hline Phenolic compound content $\left(\mu \mathrm{g} \mathrm{g}^{-1}\right)^{*}$ & $\begin{array}{l}\text { Extract of free } \\
\text { phenolics }\end{array}$ & $\begin{array}{c}\text { Extract of bound } \\
\text { phenolics }\end{array}$ & $\begin{array}{c}\text { Total } \\
\text { free and bound }\end{array}$ \\
\hline Hydroxycinnamic acid & $48.13 \pm 4.09$ & - & $48.13 \pm 4.09$ \\
\hline 5-O-caffeoylshikimic acid & $8.03 \pm 0.76$ & - & $8.03 \pm 0.76$ \\
\hline Kaempferol 3-O-7-O-diglucoside & $185.07 \pm 15.73^{\mathrm{a}}$ & $13.36 \pm 1.23^{b}$ & $198.43 \pm 14.57$ \\
\hline Phenolic 'P5' & $12.78 \pm 1.21$ & - & $12.78 \pm 1.21$ \\
\hline Protogenkwanin-4-O-glucoside & $27.03 \pm 2.29$ & - & $27.03 \pm 2.29$ \\
\hline Quercetin 3-O-glucoside-7-O-rhamnoside & $33.44 \pm 2.17$ & - & $33.44 \pm 2.17$ \\
\hline Kaempferol 3-O-rutinoside-7-O-rhamnoside & $428.55 \pm 23.57$ & - & $428.55 \pm 23.57$ \\
\hline Quercetin 3-O-rhamnoside & $46.34 \pm 3.47$ & - & $46.34 \pm 3.47$ \\
\hline Kaempferol 3-O-rutinoside & $9.58 \pm 0.58$ & - & $9.58 \pm 0.58$ \\
\hline Monocaffeoyl-meso-tartaric acid & - & $406.83 \pm 36.61$ & $406.83 \pm 36.61$ \\
\hline Kaempferol 3-O-rutinoside-7-O-glucoside & - & $50.65 \pm 4.05$ & $50.65 \pm 4.05$ \\
\hline NID 1 & - & $217.75 \pm 1.82$ & $217.75 \pm 1.82$ \\
\hline NID 2 & - & $1450.66 \pm 2.63$ & $1450.66 \pm 2.63$ \\
\hline Total & $798.95 \pm 29.05$ & $2139.26 \pm 36.99$ & $2938.21 \pm 28.44$ \\
\hline
\end{tabular}

By the gradient HPLC method, nine phenolic compounds were identified in the extract of free, and five in the extract of bound phenolics (Table 3). Among identified compounds in the extract of free phenolics, kaempferol 3-O-rutinoside-7-O-rhamnoside $\left(428.55 \mathrm{\mu g} \mathrm{g}^{-1}\right)$ was the most abundant, and the total kaempferol derivates content was $623.20 \mathrm{\mu g} \mathrm{g}^{-1}$. Among the phenolics in the extract of bound phenolics, a compound with the retention time of $67.73 \mathrm{~min}$, NID 2, was the most abundant $\left(1450.66 \mu \mathrm{g} \mathrm{g}^{-1}\right)$.

Based on the total phenolics content and the total amount of compounds observed by using HPLC methods, it is evident that only $33 \%$ of phenolics were detected. This percentage is probably higher since the Folin-Ciocalteu reagent reacts with phenolics, but also with a variety of non-phenolic reducing compounds (tertiary aliphatic amines, tryptophan, hydroxylamine, hydrazine, certain purines and organic and inorganic reducing agents) [38]. A statistical analysis showed that the investigated extracts of free and bound phenolics are different in the content of the identified compounds.

Antimicrobial activity

The antimicrobial activity of the investigated extracts is shown in Table 4.

Table 4. Antimicrobial activity of the extracts of free and bound phenolics from nettle seeds

\begin{tabular}{|c|c|c|}
\hline \multirow[b]{2}{*}{ Test microorganism } & \multicolumn{2}{|c|}{ Diameter of inhibition zone $(\mathrm{mm})$} \\
\hline & $\begin{array}{c}\text { Extract of free } \\
\text { phenolics }\end{array}$ & $\begin{array}{c}\text { Extract of bound } \\
\text { phenolics }\end{array}$ \\
\hline Proteus vulgaris ATCC 8427 & - & - \\
\hline Bacillus cereus ATCC 11778 & $12.66 \pm 1.07$ & $17.33 \pm 1.64$ \\
\hline Bacillus luteus & - & $13.00 \pm 0.91$ \\
\hline Bacillus subtilis & - & $15.66 \pm 1.17$ \\
\hline Staphylococcus aureus ATCC 25923 & - & $10.33 \pm 1.01$ \\
\hline Escherichia coli ATCC 25922 & - & - \\
\hline Pseudomonas aeruginosa ATTC 27853 & - & - \\
\hline Listeria monocytogenes ATCC 15313 & - & - \\
\hline Klebsiella pneumoniae ATTC 700603 & $11.66 \pm 1.05$ & $19.66 \pm 1.57$ \\
\hline Candida albicans ATCC 10259 & - & - \\
\hline
\end{tabular}

The extract of free phenolics had an effect on two, while the extract of bound phenolics on five of ten tested microbial species. Both of the extracts had the best inhibitory effect on the growth of the same microbial species, Bacillus cereus ATCC 11778 and Klebsiella pneumoniae ATTC 700603: the extract of free phenolics had a diameter of the inhibition zone on these bacteria of 12.66 and $11.66 \mathrm{~mm}$, while with the extract of bound phenolics it was 19.66 and $17.33 \mathrm{~mm}$, respectively. The extracts had no effect either on the growth of other investigated bacteria (Proteus vulgaris ATCC 8427, Escherichia coli ATCC 25922, Pseudomonas aeruginosa ATTC 27853, Listeria monocytogenes ATCC 15313) or on the fungi Candida albicans ATCC 10259. In literature, there are data about the antimicrobial activity of phenolics extracts from aerial parts of nettle to different bacteria and pathogenic fungi [5, 39, 40]. The Körpe et al. [41] studied 
the antibacterial activity of methanolic and aqueous extracts of Urtica devoice L. and Urtica pilulifera L. seeds on some pathogenic bacteria. These extracts had no effect on Klebsiella pneumoniae and Escherichia coli but showed a high-antibacterial activity on Pseudomonas aeruginosa and Listeria monocytogenes.

\section{Conclusion}

The investigated Urtica dioica L. seeds had a higher content of free than bound phenolics, and the extract of free phenolics had a better FRAP value than the extract of bound phenolics. By using isocratic and gradient HPLC methods, a $33 \%$ of phenolics were identified: eighteen phenolics in the extract of free phenolics with kaempferol 3-O-rutinoside-7-O- rhamnoside as the most abundant, and ten in the extracts of bound phenolics among which the monocaffeoyl-meso-tartaric acid had the highest content. The extract of bound phenolics showed a better inhibitory effect on ten tested microbial species than the extract of free phenolics, and the best among them was a negative bacterium Klebsiella pneumoniae ATTC 700603 used per gram. The results indicate that nettle seed is a good source of natural antioxidants and antimicrobials that might find a potential use in food and pharmaceutical industry.

\section{Acknowledgments}

The research is the result of a program funded by funds from the budget of the Republic of Serbia of the Ministry of Education, Science and Technological Development from the program for financing scientific research work, No. 451-03-68/2020-14/200133.

\section{References}

[1] Z. Yener, I. Celik, F. Ilhan, R. Bal, Effects of Urtica dioica L. seed on lipid peroxidation, antioxidants and liver pathology in aflatoxin-induced tissue injury in rats, Food and Chemical Toxicology, 47 (2009) 418 - 424.

[2] M. M. Cowan, Plant products as antimicrobial agents, Clinical Microbiology Reviews, 12(4) (1999) 564 - 582.

[3] P. Allardice, A-Z of companion planting, Cassell Publishers Ltd., London, 1993.

[4] Ì. Gülçin, İ. Ö. Küfrevioĝlu, M. Oktay, M. E. Buyukokuroglu, Antioxidant, antimicrobial, antiulcer and analgesic activities of nettle (Urtica dioica L.), Journal of Ethnopharmacology, 90 (2004) $205-15$.

[5] M. M. Đukić, M. Ninković, M. Jovanović, Oxidative stress-clinical diagnostic significance, Journal of Medical Biochemistry, 27 (2008) 409 - 425.

[6] Lj. Stanojević, A. Zdravković, M. Stanković, M. Cakić, V. Nikolić, D. Ilić, Antioksidativna aktivnost vodeno-etanolnih ekstrakata iz lista koprive (Urtica dioica L.), Advanced Technology, 2(1) (2013) 51 -59.

[7] B. Singh, P. J. Singh, A. Kaur, N. Singh, Phenolic composition and antioxidant potential of grain legume seeds: A review, Food Research International, 101 (2017) $1-16$.
[8] P. Y. Lin, H. M. Lai, Bioactive compounds in legumes and their germinated products, Journal of Agricultural and Food Chemistry, 54(11) (2006) 3807 - 3814.

[9] J. Hudec, M. Burdová, L. Kobida, L. Komora, V. Macho, G. Kogan, I. Turianica, R. Kochanová, O. Ložek, M. Habán, P. Chlebo, Antioxidant Capacity Changes and Phenolic Profile of Echinacea purpurea, Nettle (Urtica dioica L.) and Dandelion (Taraxacum officinale) after Application of Polyamine and Phenolic Biosynthesis Regulators, Journal of Agricultural and Food Chemistry, 55 (2007) 5689 - 5696

[10] V. Lattanzio, T. Lattanzio, A. Cardinal, In Phytochemistry: Advances in Research, F. Imperato Ed., Research Signpost, India 2006, p. 23 - 67.

[11] M. D'archivio, C. Filesi, R. Di Benedetto, R. Gargiulo, C. Giovannini, R. Masella, Polyphenols, dietary sources and bioavailability, Annali dell'Istituto Superiore Di Sanita, 43(4) (2007) 348 - 361.

[12] S. A. Letowska, J. Oszmianski, A. Wojdyło, Antioxidant activity of the phenolic compounds of hawthorn, pine and skullcap, Food Chemistry, 103 (2007) 853 - 859.

[13] B. Verma, P. Hucl, R. Chibbar, Phenolic acid and antioxidant capacity of acid and alkali hydrolysed wheat bran fraction, Food Chemistry, 116(4) (2009) 947 - 954.

[14] L. Singleton, J. Rossi, Colorimetry of total phenolics with phosphomolybdate phosphotungstic acid reagents, American Journal of Viticulture and Enology, 16 (1965) $144-158$.

[15] L. L. Mensor, F. S. Menezes, G. G. Leitão, S. Reis, D. T. Cos Santos, C. S. Coube, S. G. Leitão, Screening of brazil plant extract for antioxidant capacity by the use of DPPH free radical method, Phytotherapy Research, 15 (2001) 127 - 130.

[16] M. Oyaizu, Studies on product of browning reaction prepared from glucose amine, Japan Journal of Nutrition and Dietetics, 44 (1986) 307 - 315.

[17] I. F. Benzie, J. J. Strain, The Ferric Reducing Ability of Plasma (FRAP) as A measure of "Antioxidant Power": The FRAP Assay, Analytical Biochemistry, 239 (1996) 70 - 76.

[18] Y. Amakura, M. Okada, S. Tsuji, Y. Tonogai, Determination of phenolic acids in fruit juices by isocratic column liquid chromatography, Journal of Chromatography A, 891 (2000) 183 - 188.

[19] N. Nikolić, J. Stojanović, J. Mitrović, M. Lazić, I. Karabegović, G. Stojanović, The antioxidant activity and the composition of free and bound phenolic acids in dough of wheat flour enriched by Boletus edulis after mixing and thermal processing, International Journal of Food Science and Technology, 51 (2016) 2019 - 2025.

[20] M. Veit, C. Beckert, C. Höhne, K. Bauer, H. Geiger, Interspecific and intraspecific variation of phenolics in the genus Equisetum subgenus Equisetum, Phytochemistry, 38 (1995) 881 - 891

[21] M. J. Veličković, A. D. Kostić, S. G. Stojanović, S. S. Mitić, N. M. Mitić, S. S. Ranđelović, S. A. Đorđević, Phenolic composition, antioxidant and antimicrobial activity of the extracts from Prunus spinosa L. fruit, Hemijska Industrija, 68(3) (2014) 297 - 303.

[22] S. Otles, B. Yalcin, Phenolic compounds analysis of root, stalk and leaves of nettle, The Scientific World Journal, $2012(2012) 1-12$.

[23] A. Özkan, Ö. Yumrutas, S. D. Saygideger, M. Kulak, Evaluation of Antioxidant Activities and Phenolic Contents of Some Edible and Medicinal Plants from Turkey's Flora, Advances in Environmental Biology, 5(2) (2011) 231 - 236. 
[24] F. Pourmorad, S. J. Hosseinimehr, N. Shahabimajd, Antioxidant Activity, Phenol and Flavonoid Contents of Some Selected Iranian, African Journal of Biotechnology, 5(11) (2006) 1142 - 1145.

[25] P. Mandal, T. K. Misra, I. D. Singh, J. K. Das, M. Bhunia, Free-Radical-Scavenging Activity in the Inflorescence of European Nettle/Sisnu (Urtica dioica L.), Journal of Young Pharmacists, 1 (2009) 129 - 135.

[26] Z. Zeković, A. Cvetanović, J. Švarc-Gajić, S. Gorjanović, D. Sužnjević, P. Mašković, S. Savić, M. Radojković, S. Đurović, Chemical and biological screening of stinging nettle leaves extracts obtained by modern extraction techniques, Industrial Crops \& Products, 108 (2017) 423 $-430$.

[27] Z. Z. Kukrić, N. Lj. Topalić-Trivunović, M. B. Kukavica, B. S. Matoš, S. S. Pavičić, M. M. Boroja, V. A. Savić, Characterisation of antioxidant and antimicrobial activities of nettle leaves (Urtica dioica L.), Acta Periodica Technologica, 43 (2012) 1 - 342.

[28] Lj. P. Stanojević, M. Z. Stanković, D. J. Cvetković, M. D. Cakić, D. P. Ilić, V. D. Nikolić, J. S. Stanojević, The effect of extraction techniques on yield extraction kinetics, and antioxidant activity of aqueous-methanolic extracts from nettle (Urtica dioica L) leaves, Separation Science and Technology, 51(11) (2016) 1817 - 1829.

[29] S. Fattahi, E. Zabihi, Z. Abedian, R. Pourbagher, A. A. Motevalizadeh, A. Mostafazadeh, H. Akhavan-Niaki, Total phenolic and flavonoid contents of aqueous extract of stinging nettle and in vitro antiproliferative effect on Hela and BT-474 cell lines, International Journal of Molecular and Cellular Medicine, 3(2) (2014) 102 - 107.

[30] U. J. Vajić, J. Grujić-Milanović, J. Živković, K. Šavikin, D. Gođevac, Z. Miloradović, B. Bugarski, N. MihailovićStanojević, Optimization of extraction of stinging nettle leaf phenolic compounds using response surface methodology, Industrial Crops \& Products, 74 (2015) 912 $-917$.

[31] V. Khare, P. Kushwaha, S. Verma, A. Gupta, S. Srivastava, A. Rawat, Pharmacognostic evaluation and antioxidant activity of Urtica dioica L., Chinese Medicine, 3 (2012) $128-135$.

[32] S. M. Kataki, V. Murugamani, A. Rajkumari, S. P. Mehra, D. Awasthi, S. R. Yadav, Antioxidant, Hepatoprotective, and Anthelmintic Activities of Methanol Extract of Urtica dioica L. Leaves, Pharmaceutical Crops, 3 (2012) 38 - 46.

[33] B. A. Cvitanović, D. Komes, K. Durgo, A. Vojvodić, A. Bušić, Nettle (Urtica dioica L.) extracts as functional ingredients for production of chocolates with improved bioactive composition and sensory properties, The Journal of Food Science and Technology, 52(12) (2015) 7723 - 7734.

[34] M. P. Kähkönen, A. I. Hopia, H. J. Vuorela, J. P. Rauha, K. Pihlaja, T. S. Kujala, M. Heinonen, Antioxidant activity of plant extracts containing phenolic compounds, Journal of Agricultural and Food Chemistry, 47 (1999) 3954 - 3962.

[35] J. H. Chen, C. T. Ho, Antioxidant activities of caffeic acid and its related hydroxycinnamic acid compounds, Journal of Agricultural and Food Chemistry, (45) (1997) 2374 2378.

[36] A. Masek, E. Chrzescijanska, M. Latos, Determination of antioxidant activity of caffeic acid and p-coumaric acid by using electrochemical and spectrophotometric assays, International Journal of Electrochemical Science, 11 (2016) 10644 - 10658.

[37] P. Pinelli, F. leri, P. Vignolini, L. Bacci, S. Baronti, A. Romani,
Extraction and HPLC analysis of phenolic compounds in leaves, stalks, and textile fibers of Urtica dioica L., Journal of Agricultural and Food Chemistry, 56(19) (2008) 9127 9132.

[38] A. Gironés-Vilaplana, P. Mena, C. García-Viguera, A. D. Moreno, A novel beverage rich in antioxidant phenolics: Maqui berry (Aristotelia chilensis) and lemon juice, LWTFood Science And Technology, 47 (2012) 279 - 286.

[39] M. A. Chahardehi, D. Ibrahim, F. S. Sulaiman, L. Mousavi, Screening antimicrobial activity of various extracts of Urtica dioica, Revista de Biología Tropical, 60(4) (2012) $1567-1576$.

[40] I. Hadizadeh, B. Peivastegan, M. Kolahi, Antifungal activity of nettle (Urtica dioica L.), Colocynth (Citrullus colocynthis L. Schrad), Oleander (Nerium oleander L.) and Konar (Ziziphus spina-christi L.) extracts on plants pathogenic fungi, Pakistan Journal of Biological Sciences, 12(1) (2009) $58-63$.

[41] D. A. Körpe, Ö. D. İşeri, F. I. Sahin, E. Cabi, M. Haberal, High-antibacterial activity of Urtica spp. seed extracts on food and plant pathogenic bacteria, International Journal of Food Sciences and Nutrition, 64(3) (2013) 355 - 362. 
Izvod

\section{SEME KOPRIVE (Urtica dioica L.) KAO IZVOR SLOBODNIH I VEZANIH FENOLA: ANTIOKSIDATIVNA, ANTIMIKROBNA AKTIVNOST I SASTAV}

Jelena S. Mitrović, Nada Č. Nikolić, Ivana T. Karabegović, Bojana R. Danilović, Miodrag M. Lazić, Ljubiša B. Nikolić

Univerzitet u Nišu, Tehnološki fakultet, Leskovac, Srbija

U radu je ispitan sastav, antioksidativna i antimikrobna aktivnost ekstrakata slobodnih i vezanih fenola iz semena koprive. Sastav fenola određen je HPLC metodom, antioksidativna aktivnost određivanjem kapaciteta neutralisanja DPPH radikala, redukcione snage i FRAP vrednosti, a antimikrobna aktivnost ispitana je diskdifuzionom metodom. Sadržaj slobodnih fenola bio je veći $(6000,71 \mu \mathrm{g}$ ekvivalenta galne kiseline po g suvog semena) u odnosu na sadržaj vezanih $\left(2801,16 \mu \mathrm{g} \mathrm{g}^{-1}\right)$. Ekstrakt slobodnih fenola imao je veću FRAP vrednost od ekstrakta vezanih fenola, dok je ekstrakt vezanih fenola imao bolji kapacitet neutralisanja DPPH radikala i redukcionu snagu. U ekstraktu slobodnih fenola detektovano je osamnaest fenolnih jedinjenja među kojima je kaempferol 3-O-rutinozid-7-O-ramnozid (428.55 $\left.\mu \mathrm{g} \mathrm{g}^{-1}\right)$ bio najzastupljeniji, dok je deset fenolnih jedinjenja detektovano u ekstraktu vezanih fenola, među kojima je monokafeoil-mezo-vinska kiselina $\left(406,83 \mu \mathrm{g} \mathrm{g}^{-1}\right)$ bila najzastupljenija. Oba ekstrakta pokazala su najbolji inhibitorni efekat na rast Bacillus cereus ATCC 11778 i Klebsiella pneumoniae ATTC 700603. Rezultati istraživanja pokazuju da je seme koprive dobar izvor prirodnih antioksidanasa i antimikrobnih jedinjenja za potencijalnu upotrebu u prehrambenoj i farmaceutskoj industriji.
(ORIGINALNI NAUČNI RAD) UDK 582.635.5:547.56:543.2

Ključne reči: fenoli, seme koprive, antioksidativna aktivnost, antimikrobna aktivnost 